\title{
ANTINEOPLASTIC DRUGS: OCCUPATIONAL EXPOSURE AND SIDE EFFECTS
}

\author{
Kristīne Ivanova ${ }^{1, \#}$ and Marija Avota $^{2}$ \\ ${ }^{1}$ Faculty of Continuing Education, Rīgas Stradinš University, Dzirciema iela 16, Rīga, LV-1007, LATVIA; \\ kivanova1603@gmail.com \\ ${ }^{2}$ Faculty of Occupational and Environmental Medicine, Rīgas Stradiṇš University, Dzirciema iela 16, Rīga, LV-1007, LATVIA; \\ Marija.Avota@rsu.Iv \\ \# Correspnding author
}

Communicated by Andrejs Skaǵers

\begin{abstract}
Due to their adverse effects, antineoplastic drugs (cancer chemotherapy drugs) are considered as a potential health risk for nurses and nursing assistants. The aim of this study was to review and summarise information about acute side effects of antineoplastic drugs in two major cancer centres in Latvia. In total 51 nurses and nursing assistants participated in the study, all working in chemotherapy ward at least for 12 months. The research was conducted in Pauls Stradinš Clinical University Hospital and Riga East University Hospital, Oncology Centre of Latvia. $56.86 \%$ of respondents reported at least one side effect since working in the department of chemotherapy (DC). Headache was the most common acute side effect (37.25\%), followed by irritation of eyes $(25.49 \%)$ and irritation of skin (19.60\%). Headache $(\mathrm{p}=0.021)$, dizziness $(\mathrm{p}=0.018)$, irritation of mouth and throat $(\mathrm{p}=0.043)$, and irritation of eyes $(\mathrm{p}=0.004)$ had statistically significant positive association with years of working in $D C$, suggesting that those working for longer time in $D C$ are more likely to have headache, dizziness, irritation of mouth, throat and eyes.
\end{abstract}

Key words: antineoplastic drugs, hazardous drugs, occupational exposure, health professionals, acute side effects.

\section{INTRODUCTION}

Antineoplastic drugs have been used in treatment of cancer for more than 50 years. These powerful drugs are used clinically to destroy or control the growth or spread of cancer cells, cure the cancer or cause remission, and ease symptoms such as pain or pressure from a tumour when a cure is not possible (Anonymous, 2012). Their pharmacological property to kill tumour cells is by interfering with cell division. However, their action is not specific to cancerous cells, and non-cancerous cells may also become damaged (Shahrasbi et al., 2014).

Antineoplastic drugs are part of a larger group called hazardous drugs. Hazardous drugs are drugs that pose a potential health risk to health care workers who may be exposed during preparation or administration. Most drugs are considered hazardous if they are cytotoxic, which means that they inhibit or prevent cell function. These include biological, antiviral, and immunosuppressive agents, as well as drugs from other classes (Anonymous, 2012). Hazardous drugs are drugs manifesting genotoxicity, carcinogenicity, teratogenicity, fertility impairment, serious organ, or any other toxic manifestation at low doses in animal or human experiments (Shahrasbi et al., 2014).
Despite their therapeutic and beneficial effects in cancer patients with life-threatening conditions, both acute or shortterm and chronic or long-term adverse effects are associated with antineoplastic drugs treatment (Villarini et al., 2012). All antineoplastic drugs have side effects associated with patient use. Workers who handle antineoplastic drugs may be at risk of suffering the same effects as their patients without reaping any of the benefits (Anonymous, 2012).

The likelihood of an adverse event resulting from occupational exposure to antineoplastic drugs can vary with the dose and frequency of the exposure, and the extent to which the drug is absorbed into the body (Anonymous, 2012).

Epidemiological studies of personnel who handle antineoplastic drugs, performed on a global scale, showed detectable levels of genotoxic drugs in the work environment and a statistically significant increase in DNA damage and chromosomal aberrations in the exposed population versus the reference group (Buschini, 2013). Other studies have found increased chromosomal aberrations and evidences of mutagenic/carcinogenic risks in urine samples of exposed nurses (Shahrasbi et al., 2014).

Occupational exposure to antineoplastic drugs occurs directly and non-directly through skin absorption, ingestion, 
inhalation, or accidental injection. Both clinical and nonclinical workers may be exposed to antineoplastic drugs during the preparation, administration, or disposal of these toxic agents (Anonymous, 2012).

It is important to consider if safe work practices have been followed and in the case of a pregnant health care worker, the point during a pregnancy and/or fetal development at which the exposure occurs. Exposure to even very small concentrations of certain drugs may be hazardous for all workers who handle them. In these cases there are no safe limits (Anonymous, 2012).

In a recent study conducted in 2011 in Canada, researchers reported that nearly 17 per cent of nurses who work in outpatient chemotherapy infusion centres reported being exposed on their skin or eyes to the antineoplastic drugs they deliver (Anonymous, 2012).

Acute exposure generally causes transient symptoms such as headache, nausea, malaise, dizziness, rash, dermatitis, skin and mucous membrane irritation or ulceration, and eye or throat irritation (Shahrasbi et al., 2014). Cases of abdominal pain, hair loss, and liver damage related to cytotoxic drug exposure were also reported (Keat et al., 2013).

There are a number of long-term or chronic effects that have been identified in health care workers working with or near these potent drugs. These health effects include: liver and kidney damage, damage to the bone marrow, damage to the lungs and heart, infertility (temporary and permanent), effects on reproduction and the developing foetus in pregnant women, learning disabilities in offspring, hearing impairment and cancer (Anonymous, 2012).

Only a limited number of epidemiological studies have addressed occupational cancer risks related to handling of antineoplastic drugs. The main results reported in these studies are an increased risk of leukaemia among oncology nurses and physicians occupationally exposed to antineoplastic drugs and an elevated risk of cancer for long-term pharmacy personnel (Villarini et al., 2012). Foetal loss induced by chronic exposure to cyclophosphamide, doxorubicin and vincristine, in nursing personnel was also observed (Shahrasbi et al., 2014).

During the past 30 years, numerous guidelines have been issued to protect healthcare workers in Western countries. Although these safety precautions are intended to reduce worker exposure, recent studies have demonstrated that workplace contamination and occupational exposure continues (Yu Wen et al., 2012).

The aim of this investigation was to review and summarise information about acute side effects of antineoplastic drugs in two major cancer centres in Latvia and the possible correlation between antineoplastic drugs and work experience.

\section{MATERIALS AND METHODS}

Site observation. The report was conducted at two specialised cancer centres in Rịga, Latvia, to determine the acute side effects of antineoplastic drugs. These two centres were Pauls Stradiňš Clinical University Hospital, Department of Chemotherapy, and Rīga East University Hospital, Oncology Centre of Latvia, Department of Chemotherapy. There was large variability in antineoplastic drug usage in both centres as they did not specialise in narrow oncologic fields.

Population recruitment. A total number of 68 nurses and nursing assistants were provided with the questionnaire. All of them were women who were working in the Department of Chemotherapy for at least for 12 months. Exclusion criteria were active drinkers or smokers, known uncontrolled chronic medical conditions (cardiac problems, diabetes, arthritic related disorders and respiratory diseases), bleeding disorders, any past cancer diagnosis or active complicated medical or surgical therapies in the past 12 months. The aim of this stringent selection in terms of health and years of experience was to avoid any bias or any unrelated symptoms reported by the nursing and nursing assistant staff.

Questionnaire. The questionnaire consisted of two parts and was based on the most reputable international guidelines, such as issued by the American Society of Health System Pharmacists and the Occupational Safety and Health Administration, and the Health and Safety Executive Guidelines for handling cytotoxic drugs in clinical settings. The first part was aimed to assess knowledge of the hazardous effects, ways of exposure to cytotoxic drugs, personnel protective equipment use and safe handling measures. The second part was aimed at reporting of side effects that may be due to acute or chronic exposure to cytotoxic. Acute side effects were classified as irritation of eyes, irritation of skin, irritation of mouth and throat, dizziness, headache, nausea, vomiting, and diarrhea. The questionnaire was developed to be specific, but without causing any concerns for participants when answering the questions. The questions had to be translated from English to Latvian without any loss of meaning.

Informed written consent was obtained from all participants. Ethics approval was obtained from Rīga Stradin̄š University Ethics Committe. The research was approved by Rīga East University Hospital, Rīga Science Division, and Pauls Stradiņš Clinical University Hospital, Department of Education and Science.

Data processing. Data were analysed with MS Excel and IBM SPSS software. Descriptive statistics measured the central tendency including the mean parameters and the variability including the standard deviation, the minimum and maximum values of the variables. Inferential statistics correlations were used to determine relationships between acute side effects and participant understanding of hazards associated with their jobs and existence or lack of resources to help to minimise the risks. The $p$-value $(p<0.05)$ was used to determine statistical significance of correlations. 


\section{RESULTS}

Based on questionnaire responses and inclusion and exclusion criteria, the total number of participants included in research was 51 . Of them 29 were nurses and 22 were nursing, all assistants, all were women, with mean age of 43.39 \pm 11.105 years (range $21-63$ years). The average period of work experience in the Department of Chemotherapy was $8.63 \pm 7.11$ years, suggesting chronic exposure to a wide spectrum of antineoplastic drugs. The most frequent ways of exposure of antineoplastic drugs were cleaning of the procedure room $(60.8 \%)$, drug preparation for usage in the procedure room $(58,8 \%)$ and administering medication to patients (41.2\%) (Fig. 1). 97.1\% of respondents were informed about hazards associated with their jobs: classes and training held by the hospitals in $58.8 \%$ cases, from coworkers in $54.9 \%$, from individual studies using various literature and Internet in $47.1 \%$, from participation in conferences in $13.7 \%$, and from nursing associations and previous university training (during undergraduate training) in $11.8 \%$ of cases (Fig. 2). All respondents were informed about available resources to help minimise occupational hazardous risks, but only $90.2 \%$ regularly used protective equipment during work. $31.37 \%$ of respondents noticed overall decline of health since working in the Department of Chemotherapy, but there was no statistically significant relationship between ways of exposure of antineoplastic drugs $(p \geq 0.05)$, information about hazards associated with their jobs $(p \geq 0.05)$, and regular usage of protective equipment during work $(p \geq 0,05)$.

$56.86 \%$ of respondents stated at least one side effect since working in the Department of Chemotherapy. Using the validated questionnaire, we aimed to determine the prevalence of acute adverse effects. Headache was the most common acute side effect, reported in 19 cases $(37.25 \%)$, followed by irritation of eyes, reported in 13 cases $(25.49 \%)$, hair loss, reported in 11 cases $(21.6 \%)$, irritation of skin, reported in 10 cases $(19.60 \%)$, dizziness, reported in 7 cases $(13.72 \%)$, and irritation of mouth and throat, reported in 4 cases $(7.84 \%)$ (Fig. 3). Skin irritation was considered any rash and skin redness (dermatitis-like reactions) while working with cytotoxic agents. In all cases nurses confirmed that they had no other reasons or life style changes to be the cause for such reactions. The questions presented to the nurses were "In general, have you experienced more episodes of hair loss while working in your current wards?" and "In general, have you experienced more episodes of nausea and vomiting while working in your current ward?"

All reported side effects had positive relationship with years of working in the Department of Chemotherapy, showing higher frequency of side effect in nurses and nursing assistants with longer occupational exposure to antineoplastic drugs. Headache $(p=0.021)$, dizziness $(p=0.018)$, irritation of mouth and throat $(p=0.043)$, and irritation of eyes $(p=0.004)$ had statistically significant positive relationship with years of working in the Department of Chemotherapy while other side effects lacked significant correlation $(p \geq$ $0.05)$. None of respondents reported newly discovered re-

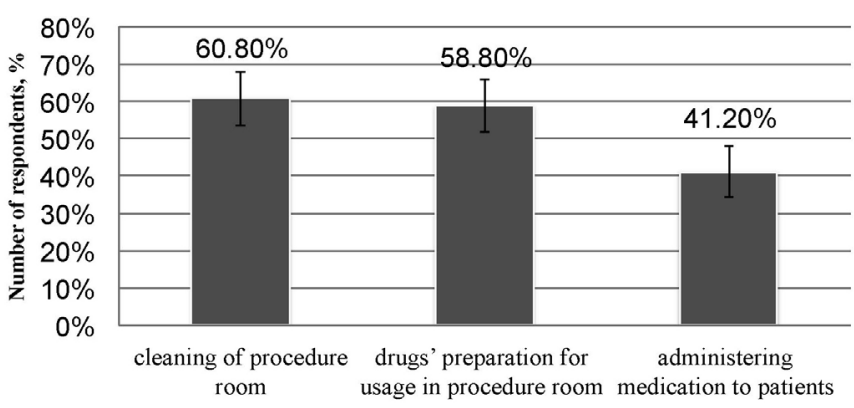

Fig. 1. The most frequent ways of exposure of antineoplastic drugs. Questionnaire responses from 51 healthcare workers, including 29 nurses and 22 nursing assistants.

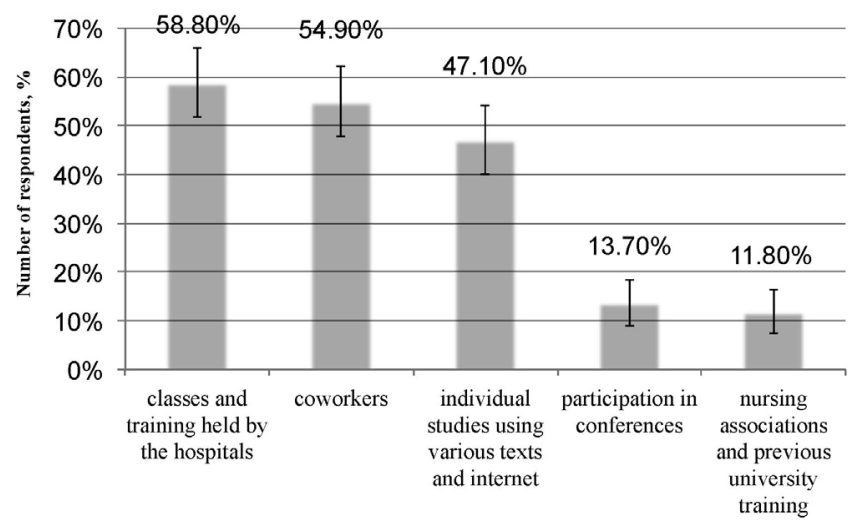

Fig. 2. Sources of information about occupational hazards. Questionnaire responses from 51 healthcare workers, including 29 nurses and 22 nursing assistants.

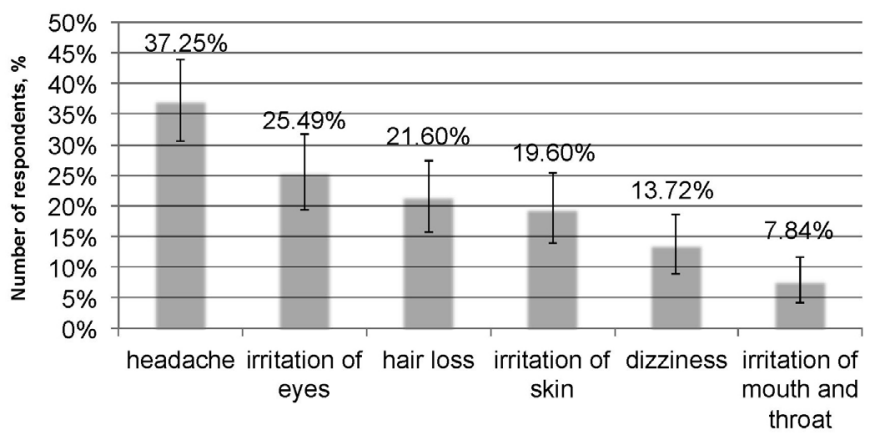

Fig. 3. Acute side effects since working in the Department of Chemotherapy. Questionnaire responses from 51 healthcare workers, including 29 nurses and 22 nursing assistants. 56.86\% of respondents reported at least one side effect since working in DC.

productive challenges or oncological diseases since working in the Department of Chemotherapy.

\section{DISCUSSION}

This study was based on questionnaire and was carried out in two different parts: to assess the level of training and knowledge of the nurses and nursing assistants on risks associated with cytotoxic drugs and to investigate the level of acute side effects that were associated with occupational exposure to chemotherapy agents. 
This study appears to be the first local investigation of the nurses' safety-related knowledge, attitude and practices in cytotoxic drug handling in a general hospital. To our knowledge, it is also the only study, which demonstrates the possible acute side effects related to handling cytotoxic drugs.

Although there was possibility to compare level of training and knowledge of the nurses and level of acute side effects between the two hospitals, due to the limited number of nurses and nursing assistant included in this study.

This study showed moderate level of knowledge of the nurses and nursing assistants about possible occupational exposure to antineoplastic drugs. The most common source of information was classes and training held by the hospitals, followed by co-workers and individual studies using literature and Internet. Other studies have also shown that hospitals are the main providers of information about safe handling of drugs and associated risks.

Although all respondents were informed about available resources to help minimise occupational hazardous risks, only $90.2 \%$ regularly used protective equipment during work and this difference may be even bigger if we take into account subjectivity of survey. We found slightly higher incidence of overall decreasing of health status since working in the Department of Chemotherapy in respondents who did not regularly use protective equipment, but this effect was not statistically significant.

More than a half of respondents reported at least one side effect since working in the Department of Chemotherapy. Rarely there was only one marked side effect. The most frequent reported acute side effect was headache, followed by irritation of eyes, hair loss, irritation of skin, and dizziness. There were no reported cases of nausea, vomiting and diarrhea. In studies from other countries, irritation of skin was the most frequent side effect, which might be explained by a lower level of protective equipment usage. However, headache is a less reliable side effect to indicate occupational risk of cytotoxic drugs, due to the broad spectrum of other conditions that can cause this symptom.

All reported side effects were more common in respondents with longer working experience in the Department of Chemotherapy, showing possible cumulative effect of cytotoxic drugs on human organism. This relationship was statistically significant for four side effects: headache, dizziness, irritation of mouth and throat, and irritation of eyes.

The most acknowledged chronic side effects of antineoplastic drugs associated with occupational exposure are reproductive challenges (infertility, spontaneous abortions, and congenital malformations) and oncological diseases (leukaemia, Non-Hodgkin lymphoma, breast, bladder, and liver cancers). In our study none of respondents reported newly discovered reproductive challenges or oncological diseases since working in the Department of Chemotherapy.

\section{CONCLUSIONS}

Considering the findings, one of the most important steps to improve healthcare worker participation in safe handling of antineoplastic drugs and possibly to decrease the incidence of acute side effects related to these agents in both hospitals would be to conduct regular training for all potentially exposed workers in workplaces where antineoplastic drugs are used, to implement a programme for safely handling of hazardous drugs at work and to review this programme annually on the basis of workplace evaluation, and promoting good practices and safety procedures among all the professionals that handle antineoplastic drugs. In addition to preventing exposure to hazardous drugs and carefully monitoring the environment, medical surveillance is an important part of any safe handling programme for antineoplastic drugs. The best practice would be participation in medical surveillance programmes provided by the workplace, increasing the frequency of check-ups for persons with longer work experience and using past exposure history of workers as a surrogate measure of potential exposure intensity.

\section{ACKNOWLEDGEMENTS}

We would like to thank medical and nursing teams of Pauls Stradiň̌ Clinical University Hospital, Department of Chemotherapy, and Rìga East University Hospital, Oncology Centre of Latvia, Department of Chemotherapy, who have participated in this research throughout.

\section{REFERENCES}

Anonymous (2012). Antineoplastic drugs: Hazardous, handle with care. ONA (Ontario Nurses Association) - Local 100 Newsletter, December, $7-13$.

Buschini, A., Villarini, M., Feretti, D., Mussi, F., Dominici, L., Zerbini, I., Moretti, M., Ceretti, E., Bonfiglioli, R., Carrieri, M., Gelatti, U., Rossi, C., Monarca, S., Poli, P. (2013). Multicentre study for the evaluation of mutagenic/carcinogenic risk in nurses exposed to antineoplastic drugs: Assessment of DNA damage. Occup. Environ. Med., 70 (11), 789-794.

Gómez-Olivįn, L. M., Miranda-Mendoza, G. D., Cabrera-Galeana, P. A., Galar-Martínez, M., Islas-Flores, H., SanJuan-Reyes, N., Neri-Cruz, N., García-Medina, S. (2014). Oxidative stress induced in nurses by exposure to preparation and handling of antineoplastic drugs in Mexican hospitals: A multicentric study. Oxid. Med. Cell. Longevity, 2014, 7.

Keat, C. H., Sooaid, N. S., Yun, C. Y., Sriraman, M. (2013). Improving safety-related knowledge, attitude and practices of nurses handling cytotoxic anticancer drug: Pharmacists' experience in a general hospital, Malaysia. Asian Pacif. J. Cancer Prevent., 14 (1), 69-73.

Lawson, C. C., Rocheleau, C. M., Whelan, E. A., Lividoti Hibert, E. N., Grajewski, B., Spiegelman, D., Rich-Edwards, J. W. (2012). Occupational exposures and spontaneous abortion. Amer. J. Obstetrics Gynecol., 206 (4), e1-e8.

Momeni, M., Danaei, M., Askarian, M. (2013). How do nurses manage their occupational exposure to cytotoxic drugs? A descriptive survey in chemotherapy settings, Shiraz, Iran. Int. J. Occup. Environ. Med., 4 (2), 102-106.

Anonymous (2014). NIOSH List of Antineoplastic and Other Hazardous Drugs in Healthcare Settings 2014. U.S. Department of Health and Human Services Centers for Disease Control and Prevention, National Institute for Occupational Safety and Health, DHHS (NIOSH) Publication No. 2014-138. 
Shahrasbi, A. A., Afshar, M., Shokraneh, F., Monji, F., Noroozi, M., Ebrahimi-Khojin, M., Madani, S. F., Ahadi-Barzoki, M., Rajabi, M. (2014). Risks to health professionals from hazardous drugs in Iran: A pilot study of understanding of healthcare team to occupational exposure to cytotoxics. Exper. Clin. Sci. Int. Online J. Adv. Sci., 13, 491-501.

Villarini, M., Dominici, L., Fatigoni, C., Muzi, G., Monarca, S., Moretti, M. (2012). Biological effect monitoring in peripheral blood lymphocytes from subjects occupationally exposed to antineoplastic drugs: Assessment of micronuclei frequency. J. Occup. Health, 54 (9), 405-415.

Yu Wen, H., Le, J., Mei, Bian, Z. Quan, Z., Xiao Feng, Y., Xu Dong, H., Ying, Z., Ji Liang, H. (2012). An investigation of oxidative DNA damage in pharmacy technicians exposed to antineoplastic drugs in two Chinese hospitals using the urinary 8-OHdG assay. Biomed. Environ. Sci., 25 (1), 109-116.

Received 3 November 2015

\section{ANTINEOPLASTISKĀS VIELAS: ARODA EKSPOZĪCIJA UN BLAKNES}

Antineoplastiskās vielas, kas tiek izmantotas ḷaundabīgo audzēju ārstēšanā k̦īmijterapijas veidā, tiek uzskatītas par potenciāliem veselību apdraudošiem riskiem māsām un māsu palīgiem šo vielu izraisītu blakusefektu dēl, Šì pētījuma mērķis bija savākt un apkopot informāciju par antineoplastisko vielu izraisītiem akūtiem blakus efektiem divos lielākajos onkoloğijas centros Latvijā. Aptauja tika veikta Paula Stradiņa klīniskajā universitātes slimnīcā un Rīgas Austrumu klīniskās universitātes slimnīcas Latvijas Onkolog̣ijas centrā. Kopumā tika aptaujāta 51 māsa un māsu palīgi, visi kīmijterapijas nodạ̣ā bija strādājuši vismaz 12 mēnešus. 56,86\% respondentu atzīmēja vismaz vienu blakni kopš darba uzsākšanas ḳīmijterapijas nodą̧ā. Biežāk minētās akūtās sūdzības bija galvassāpes (37,25\%), acu (25,49\%) un ādas kairinājums $(19,60 \%)$. Galvassāpes $(p=0,021)$, reibonis $(p=0,018)$, mutes, rīkles kairinājums $(p=0,043)$ un acu kairinājums $(p=0,004)$ uzrādīja statistiski ticamu pozitīvu saistību ar darba stāžu kīmijterapijas nodaḷā, liekot secināt, ka darbiniekiem ar lielāku darba stāžu kīmijterapijas nodạ̣ā ir lielāka iespēja attīstīties galvassāpēm, reibonim, mutes, rīkles un acu kairinājumam. 